\title{
REVIEW -A LIFE FOR NOBEL PRIZE, REMEMBER GEORGE EMIL PALADE
}

\author{
Mirela E. CADAR* and Mircea GABOREANU
}

Faculty of Animal Science and Biotechnologies, University of Agricultural Sciences and Veterinary Medicine, 3-5 Mănăștur Street, 400372 Cluj-Napoca, Romania

*Corresponding author, email:mirucadar@yahoo.com

Bulletin UASVM Animal Science and Biotechnologies 71(2) / 2014,

Print ISSN 1843-5262; Electronic ISSN 1843-536X

DOI: 10.15835/buasvmcn-asb:10484

\begin{abstract}
Four decades ago, the Nobel Prize for Medicine and Physiology honored and rewarded the activity in Cellular and Molecular Biology domain of three researchers, Albert Claude (1899-1983), Christian De Duve (1917-2013) and George Emil Palade (1912-2008). Viewing the life and activity history of GE Palade comes out his respect for a certain research ethics and his demeanor for his very numerous collaborators and disciples.
\end{abstract}

Keywords: cellular biology, molecular biology, Nobel Prize, GE Palade

\section{INTRODUCTION}

Four decades ago, the Nobel Prize for Medicine and Physiology honored and rewarded the activity in Cellular and Molecular Biology domain of three researchers, two Belgians -Albert Claude (18991983) and Christian De Duve (1917-2013) and an American of Romanian origin -George Emil Palade (1912-2008). The motivation of Nobel Committee was "For discoveries concerning the functional organization of the cell that were seminal events in the development of modern cell biology".

\section{2, Iaşi Romania}

GE Palade was born in November 19, 1912 in Iași, Romania, in a family in which both parents (father Ioan Emil Palade, 1885-1961 and mother Constanţa Cantemir Palade, 1886-1976) and also grandparents had intellectual professions (professors, schoolteachers, reverends). GE Palade had two sisters, Adriana who became Geography teacher and Constanţa, pediatric physician.

\section{0, Bucharest Romania}

After graduation of high school in 1929, GE Palade was admitted at Carol Davila School of Medicine from Bucharest, Romania and received his MD in 1940. During the first university years, GE Palade revealed a special interest for biochemistry and anatomy. His PhD thesis was of anatomy domain with the theme "The nephron of cetacean Delphinus delphi".

After university graduation, GE Palade worked for a short time as assistant in the Clinic of Internal Diseases, and than he returned at Anatomy Discipline, where in few years became assistant, lecturer and associated professor. The chief of Anatomy Discipline was Professor Grigore T. Popa, which in 1930 during a research stage at Cambridge University has discovered and described with Unna Fielding the hypophysial portal vessel system.

GE Palade married in 1944 Irina Malaxa, physician and daughter of Nicolae Malaxa -the magnate of heavy Romanian industry. In 1945 was born Georgia, the first child, and the second one Philip, will be born in 1957 in USA.

\section{6, New York USA}

In 1946, GE Palade with his wife and daughter emigrated in USA, with the wish to continue their studies. Having a letter of introduction from professor Grigore T. Popa to Robert Chambers from New York University, Department of Biology, GE Palade was accepted as "Visiting Investigator". Here, during few months, he continued his morpho-functional study of kidney, for this time 
on in vitro cultures of renal tissue from chicken embryos, and the results guiding to his first published article in USA in 1947. In the same year, being invited by Albert Claude, GE Palade goes to Rockefeller Institute for Medical Research, where he will stay 25 years. There, Albert Claude had also as collaborators the naturalist Keith Porter, the physician George Hogeboom and the biochemist Walter Schneider. The preoccupations of this researchers' group, which GE Palade named "the first Rockefeller group", were focused mainly in two directions: cell fractionation for organelle separation and their biochemical analysis and biological sample examination in electronic microscope.

Albert Claude initiated cell fractionation and ultracentrifugation of cellular homogenate since 1940 , and he succeeded to isolate only small vesicular structures, named microsomes.

GE Palade improved this technique performance conceiving the procedure known as "ultracentrifugation in sucrose density gradient".

Albert Claude with Keith Porter used for the first time in 1947 an electronic microscope of industrial type for cell study. Examining a singlelayer cell culture they described in cells' very thin cytoplasm a structure with lace aspect, vaguely contoured, which was named endoplasmic reticulum.

In Rockefeller Institute the first electronic microscope was made in function in 1948. It use in biological research imposed ultrafine sections, thick of only 50-150 nm, and a more correct chemical fixation of subcellular structures, which allows obtaining optimal resolution on images. These difficulties were surpassed when was invented the ultramicrotome by Keith Porter and Johan Blum and the fixation method of biological samples with a osmium tetraoxyde buffered with sodium veronal at 7.0-7.5 pH, conceived by GE Palade and known as "fixative of Palade".

With these means, "the first Rockefeller group" achieved the isolation of mitochondria from hepatocytes (1947), their cytochemistry and demonstration of Golgi apparatus presence in somatic cells (1949).

In 1949, the researchers' group from Rockefeller Institute diminished by departure of Albert Claude, Walter Schneider and George Hogeboom, but with Keith Porter and GE Palade came the neurophysiologists Herbert Gasser and
Sanford Palay, the botanist Ruth Sager and a longdistance collaborator (from 1954 until 1961) the biochemist Philip Siekevitz, all together forming "the second Rockefeller group".

During the activity of this group, GE Palade described for the first time the structure of mitochondrion with all its aspects from different cellular type, named cristae mitochondriales the prolongations inside them and demonstrated that mitochondria are permanent organelles in cytoplasm of all eukaryotic cells.

When he published these data, GE Palade became a naturalized American citizen.

Togetherwith Keith Porter,GEPaladecontinued the study of endoplasmic reticulum, for this time on ultrafine slides, describing its two aspects: rough or granular endoplasmic reticulum and smooth or agranular endoplasmic reticulum. They studied the same organelle in muscular fibers and named it sarcoplasmic reticulum.

GE Palade with Philip Siekevitz had demonstrated that cytoplasmic subcellular structures described by Keith Porter and named microsomes, are in reality vesicular fragments derived from endoplasmic reticulum during cells' fractioning.

But, one of the most important discoveries of GE Palade was that of cytoplasmic structures, which he named "small granular components of cytoplasm" being either free in cytosol, isolated or grouped or attached to endoplasmic reticulum surface. These structures were subsequently named granules of Palade, ribonucleoproteic particles, and nowadays are named ribosomes.

The study of endoplasmic reticulum and ribosomes was continued as biochemical one, in collaboration with Philip Siekevitz. Were developed experiments with tracer atom aminoacids marked with radioactive isotopes concluding that these cytoplasmic structures have as main function the protein synthesis.

In same period GE Palade, having as laboratory chief the neurophysiologist Herbert Gasser (Nobel Prize 1944) targeted his researches also on electrono-microscopic study of nervous tissue. For the first time there were marked out the nervous fibers of $\mathbf{C}$ type leading the pain sensation, and was named the mesaxon as an annexed structure of them. The collaboration with Sanford Palay, also neurophysiologist, gave to GE Palade the opportunity to demonstrate the fact that Nissl bodies or granulations from optical 
microscopy are in electron microscope dense packs of flattened sacks of granular endoplasmic reticulum. GE Palade was also those one who first described the inter-neuronal and neuromuscular synapse ultrastructure, with the two portions, pre- and post-synaptic elements, the presence of synaptic vesicles and existence of synaptic cleft, thus demonstrating the contiguity relation and not continuity one between neurons.

Collaboration with the botanist Ruth Sager leaded to study the chloroplast ultrastructure from green algae, thus demonstrating that beside them, in vegetal cells, is also present the endoplasmic reticulum.

In 1957, GE Palade in collaboration with the anatomist Benet Russel conceived the method with potassium telurit to make evident dehydrogenases' activity in electron microscope, fact that allows for them to ascertain the activity intensity of these enzymes inside mitochondria. In same period, GE Palade made with the biochemist Philip Siekevitz a biochemical study of endoplasmic reticulum and of ribosomes from cells of Guinea pig exocrine pancreas.

Pursuant to intercessions of Keith Porter and GE Palade starting of 1955 appeared the Journal of Biochemical and Biophysical Cytology. In further years, GE Palade was member in Editorial Board of Journal of Molecular Biology, Journal of Membrane Biology, Journal of Cell Biology and Annual Review of Cell Biology.

In 1961, "the second Rockefeller group" chan ged its composition because of departure of Keith Porter and Philip Siekevitz. The laboratory activity was further coordinated by GE Palade, to who joined in time a large number of researchers from USA, Canada, Sweden, Italy, Germany, Hungary, Israel, Great Britain and Romania. Among these, some are professors with approved scientific notoriety, as the anatomist Ewald Weibel, the pathologist Guido Majno, the biologist and pathologist Marilyn Gist Farquhar, the physician Nicolae Simionescu and his wife biologist Maya Simionescu, the biochemists Lars Ernster, Gustav Dallner, Tsuneo Omura, Itzhak Ohad and Johan Kirsch, and the biophysicist Lucien Caro. Other ones, scholars of post-doctoral studies, as Steve Wissing, Francesco Clementi, Rudolph Burns, and many young medical under-graduated as James Jamieson, Colvin Redman, Yutaka Tashiro, Lewis Joel Green, Any Leskes, Alan Tartakoff and Günter
Blobel. Starting 1978, there came also 14 postdoctoral physicians, geneticists and biochemists from Romania. In next 12 years of activity, the main preoccupations of GE Palade with mentioned collaborators were: the intracellular aspects of protein secretion process, the ultrastructure of endothelium of blood capillaries, the mechanisms of capillaries' permeability and cytomembrane biogenesis.

During 1962-1964, GE Palade in collaboration with Lars Ernster, Lewis Joel Green, Johan Kirsch, Colvin Redman, Gustav Dallner, Any Leskes and more often with Lucien Caro and James Jamieson effected majority of experiments through of were proved the protein secretion phases in glandular cells of exocrine pancreas, both in vivo and in vitro. In this study unless electron microscopic examinations were done complementary techniques as: cellular fractionation, separation of cellular components (endoplasmic reticulum, Golgi vesicles, mitochondria, secretion vesicles and granules etc.) by ultracentrifugation in sucrose density gradient. Also, were used as tracer atoms of some aminoacids marked with radioactive isotopes as $\left[{ }^{3} \mathrm{H}[-\right.$ leucine, by pulsechase analysis followed by autoradiographic examination in electron microscope. In this way can be characterized the synthesis phase of polypeptides at ribosome level, the segregation phase of them inside cisternal endoplasmic reticulum, the intracellular transport phase by transitional elements of endoplasmic reticulum and peripheral Golgi vesicles, the concentration phase in condensing vesicles, the intracellular storage phase in zymogen granules and, finally, the discharge phase with membrane fusion and fission interactions, which take place in final phase.

During 1963-1964, GE Palade in collaboration with the biochemists of team had done cytochemistry researches on exocrine pancreatic cells from Guinea pig, rat, pigeon and bovines specifying the biochemical nature of condensing vacuoles, of zymogen granules and those ones of secretion. In an interview for a journal of New Haven USA, GE Palade summarized this activity saying "All of us we known that in an organism with evolved structure almost all cells product proteins. I identified this process".

Also in 1964, GE Palade with James Jamieson were the first ones which discovered and described 
in electron microscope thepresencein atrial cardiac muscle of some secretion granules, which were named specific atrial granules. Subsequently in 1981, De Bold and his collaborators established that these granules contained a hormone, which was named atrial natriuretic factor (ANF).

During 1962-1967, GE Palade started the study of cellular membrane biogenesis with James Jamieson, Philip Siekevitz, Gustav Dallner, Any Leskes, Itzhak Ohad, Tsuneo Omura, Jacopo Maldonesi and Lars Ernster. Succeeding the isolation of endoplasmic reticulum membranes without ribosomes and their analysis on rat hepatocytes, can be estimated the membrane proteins' turnover. For the membranes of tilakoid bodies were used cells of green algae. Thus, can be demonstrated that in cells are not produced new membranes ("de novo"), but the structural proteins and synthesized and segregated enzymes are incorporated in pre-existent membranes' structure. From this phenomenon results the continuity in time, the organization and functional continuity of cellular membranes.

Another research theme that was developed great part concomitantly with previous ones was the study of blood capillaries' endothelium and its role in permeability process. GE Palade started this study from 1960 in collaboration with Rudolph Burns, Steve Wissing, Ewald R. Weibel, Francesco Clementi and Guido Majno. But, the most articles were published in collaboration with Marilyn G. Farquhar, specialist in zoology and experimental pathology, who came at Rockefeller Institute in 1961. She married GE Palade in 1970, after one year of first wife Irina death.

The first researches targeted the renal glomerular capillaries specifying the ultrastructure of urinary filtration barrier and marking out for the first time the presence of a third cell type, with phagocytary role, in connective matrix of stalk region of the capillary tuft, which were named mesangial cells.

Also, on this capillary type, but in rats with nephritic syndrome, they had described for the first time a special type of occlusive intercellular junctions, which were named occluding zonules.

Extending the study of intercellular junctions also on other epithelia types, GE Palade and Marilyn Farquhar described other two junctions' types, which were named zonula adherens and macula adherens or desmosomes. For these discoveries, in the open speech of Symposium "Junctional Complexes of Epithelial Cells" in London 1987, GE Palade and Marilyn Farquhar were named "grand parents of intercellular jonctional systems".

In a morphometric study of pulmonary arterial vascularization made in 1964 by GE Palade and Ewald R. Weibel -anatomy professor in University of Bern Switzerland and the president of International Society of Stereology- marked out for the first time in electron microscope the existence of some "new components from arterial endothelial cells" further named Weibel-Palade bodies. In present, it is known that these ones contain one of numerous blood clotting factors, named Von Willebrand factor.

The researches of GE Palade concerning permeability of different blood capillary types were started almost in 1961 when, in collaboration with Marylin Farquhar and Steve Wissing had tested the renal glomerular capillary permeability using as tracer atoms molecules of feritine. The experiments were continued in collaboration with Rudoph Bursn on capillaries from muscles, with Francesco Clementi on capillaries from intestine, and with Guido Majno had studied the effect of histamine and serotonine on capillary permeability in case of inflammatory process. During these experiments, GE Palade observed and described in electron microscope an unprecedented transport modality of some molecules by plasmalema invagination forming carrier vesicles, which were named plasmalemal vesicles. The phenomenon was named transcytosis.

The study of capillary endothelium permeability became almost the unique preoccupation with arrival in 1970 at Rockefeller Institute of the physician Nicolae Simionescu and his wife, the biologist Maya Simionescu, invited by GE Palade in 1970 when he visited Romania. The collaboration in this "famous Romanian trio", as was named in specialty groups, subsisted 10 years. The test of endothelium permeability was done with anionic and cationic molecular tracer atoms having different size molecules as: feritine, peroxydase, myoglobine, dextran, glycogen and N-peptids. Came out that beside the plasmalemal vesicle pathway the endothelium crossing is possible also by nonpermanent transendothelial channels, which are formed by certain vesicles' junction. Also, came out that these transport ways depends on electrical charge of transported molecules. Moreover, it 
intervenes also the chemical interaction between transportable molecules and certain receptors from endothelial cell membrane, process that was named transcytosis mediated by receptors. All these observations constituted the start basis to study the arteriosclerosis ethiopathogeny further done by Nicolae and Maya Simionescu at Institute of Cellular Biology and Pathology from Bucharest, Romania. Given to the experience in this domain of the two Romanian disciples of GE Palade, is not surprising the fact that Leon Weiss -the editor of well-known book "Cell and Tissue Biology" ( $6^{\text {th }}$ edition, 1988)- consigned the chapter "The Cardiovascular System" to Simionescu family, and the chapter "The Exocrine Pancreas" to James Jamieson, which had the longest collaboration with GE Palade for protein synthesis study in pancreatic cells.

In 1973, the new manager of Rockefeller Institute, the physicist Frederick Steitz, do not agree the existence of some large research team and the multi-disciplinary approaching of research themes, fact that constituted a permanent cause of disagreements with GE Palade. Moreover, in Institute were organized in addition 5 research laboratories, all in Cellular and Molecular Biology domain. This situation motivated GE Palade to accept the invitation to establish and lead a Molecular Medicine Center and to teach Cellular Biology for students in Yale University, School of Medicine New Haven, Connecticut USA. The transfer was done in 1974, with GE Palade departing his wife Marilyn, James Jamieson, Nicolae and Maya Simionescu, David Castle and Ann Hubbard.

\section{4, New Haven, Connecticut USA}

The Rockefeller University, New York, that in his history had four Nobel Prize laureates (Alexis Carrel-1912, Karl Landsteiner-1930, Herbert Gasser-1944 and Payton Rous-1966) had failed their continuation list with another three ones. And this was because in October 1974, were communicated the names of the three Nobel Prize laureates for Physiology and Medicine: Albert Claude -manager of Jules Bordet Institute from Bruxelles, Belgium, Christian De Duve - professor of biochemistry in Catholic University of Louvain, Belgium, and George Emil Palade - professor in Yale University, New Haven USA.
David Baltimore (Nobel Prize 1975) wrote in his book "Molecular Cell Biology" (1986): "Many of the first identifications of cellular structures in electron microscopy as well some biochemical characterizations of cellular functions we do to researches of Albert Claude and his three collaborators: Christian De Duve, George Emil Palade and Keith Porter. The sophisticated image that we have about cell structure and function is, in large part, the fruit of their research. They were the architects of modern Cellular Biology".

The title of this review limits the subject only for the life and work of GE Palade, without losing track of the fact that researches and discoveries of the other two Nobel Prize laureates -Albert Claude and Christian De Duve- had same importance for modern Cellular Biology development and with practical consequences in cellular pathology.

In Yale University, GE Palade had activated between 1974 and 1990 as professor and chairman of Cellular Biology Division as well as Senior Research Scientist of Cellular Biology Department. His wife, Marilyn activated as Sterling Professor of Cellular Biology. In this period, GE Palade and his collaborators had continued the study of transcytotic transport system of large molecules through endothelial barrier, started in 1972.

\section{0, San Diego California, USA}

In 1990, GE Palade moved at California San Diego University, School of Medicine La Jolla, USA, where he activated as Professor of Medicine of Residence and as Dean of Scientific Affairs in Cellular and Molecular Medicine Department, and his wife Marilyn as professor of Pathology.

In San Diego, GE Palade continued the researches for vectorial transport of intracellular proteins with a numerous research team, among who were the Romanian physicians Lucian Săucan and Dan Predescu. But, now instead of ultracentrifugation in sucrose density gradient, considered out of date, was used the immuneisolation procedure to separate the cytoplasm components. Thus, can be followed the route of synthesized proteins at ribosome level, in their way to approximate 25 possible destinations (endoplasmic reticulum, Golgi complex, lysosomes, membranes etc.). It can be established that each protein type possesses an encoded signal, formed by few aminoacids, which will be recognized by a specific receptor from the 
membrane of destination cellular component. Was even succeeded the identification and isolation of such signals and receptors.

Concomitantly, GE Palade was involved in promotion of Cellular and Molecular Biomedical Problems activating as advisor in National Scientific Foundation and in National Institute of Health. In his Banquet Speech, in Stockholm, December 10, 1974, GE Palade declared that: "We feel that the new distinction acknowledges beyond us, beyond personal achievements the rebirth of our field of knowledge and the vistas it has opened for the medicine of tomorrow".

And indeed, in further period, new knowledge from Cellular and Molecular Biology lead to identification of numerous disease causes as, for example, those ones of mitochondrial and lysosomial origin, which form today the object of Cellular Pathology.

\section{8, the last gong}

In the last period of his life, GE Palade was affected by a severe form of visual retina degeneration, very probably as consequence of countless hours of visual effort on the small luminescent screen of the electron microscope.

GE Palade passed away in October 7, 2008, at age of 96 years in his home from Del Mar California. His ashes, as he wanted, was bring in Romania by Philip and Georgia (son and daughter) and was let go in the wind from "Vârful cu Dor" ("Nostalgia Peak") - Meridional Carpathians.

From his family, Marilyn Farquhar Palade remained in San Diego, his daughter Georgia married Van Dussen lives in USA, as well the son Philip, professor of neurophysiology in Galverstone University, Texas USA. Also, he had three nephews: the physician and bacteriologist Anca Israil and the surgeon Radu Palade, from his sister Adriana marriage with the jurist Mihai Dumitri Israil, and Irina Alexandra Matiu, physician in Huston, Texas USA, from his sister Constanţa marriage with the physician Ionescu Matiu.

\section{George Emil Palade and research ethics}

Viewing the life and work history of GE Palade, it keeps attention his respect for a certain ethics of research. A prime aspect is that we can deduce when he received the Nobel Prize his first appreciation words were "for the workings of fate, which we do not control, and which made our achievements possible".

Then, it is his demeanor given to very numerous colleagues and disciples, about whom he said that "they were devoted, skilled and less recognized, without whom our advances would have been less impressive".

At the end of Nobel Lecture conference, with title "Intracellular aspects of the process of protein secretion", GE Palade marked the names of 16 collaborators in this theme research naming them "Good colleagues and comrades to whom I dedicate this work with affection and recognition for the accomplished work".

His collaborators, young in majority, came not only from USA but also from many other countries, GE Palade having the conviction that "At their best the human minds belong to mankind, above nations and above any frontier" and that "The science has an international character and do not develop in isolation".

In the numerous published articles, we often remark that GE Palade put, as recognition sign, as first author his young collaborators. Many of them, at the specialization period end had developed in their countries Cellular Biology Centers, thus becoming specialists of international notoriety. Such, for example, it was the case of Philip Siekevitz, James Jamieson, Yutaka Tashiro, Tsuneo Omura, Nicolae and Maya Simionescu etc.

James Jamieson, past student of GE Palade, became professor in Cellular Biology Department of Yale University. He organized the "GE Palade EM Slide Collection" where are kept and can be studied the electron microscopic images made by GE Palade during 1948-1990, images which are free accessible in entire world via Internet.

In case of Nicolae and Maya Simionescu, the intersession of GE Palade at Romanian state authorities and his contribution with equipments and funds lead to establish in 1973 in Bucharest the Institute of Cellular Biology and Pathology, which had as manager until 1995 the professor Nicolae Simionescu, and after that his wife Maya. Starting with 1978, a large number of medical undergraduate students from this Institute were accepted as scholars for post-doctoral study in laboratories of GE Palade from Yale University.

As concerns the research managing, GE Palade considered that "Researchers must develop free their ideas, but with the quality control of 
projects and results". He believed also that "It must be avoided the effort concentration to resolve a certain problem concentrating massive work forces and resources. It needs accumulation of data and facts to reach a critical mass of basis knowledge. In this moment, we can formulate an applied research project and could be proposed a target. But until then, it is only lost time, wasted resources and disappointed expectations". But, GE Palade considered that "We must habituate with the short life of discoveries, because the ideas for eternity are few".

As concerns the scientific discovery priority conferred as a rule to those one who is the first that publish his results, GE Palade considered that could be equally associated with "those one who bring the most illustrative and solid arguments for the research theme".

Early his student period he was influenced by his professors, the anatomists Francisc Rainer and Grigore T. Popa and by the biochemist André Boivin, GE Palade considered in the spirit of functional structure conception that "To discover a certain structure is not a big thing if you don't succeed to make out also what function accomplish" as well that "The significance of vital phenomenon can be understood only descending to molecular level, practicing a concrete, deepened and multidisciplinary experiment".

In connection with this concept, we can tell a story during a conference of GE Palade with the subject "Structure and function of endoplasmic reticulum" in 1964 at Chemistry Institute from Cluj Romania. During the dissertation, when he used images with endoplasmic reticulum abundant in exocrine pancreas cells, he mentioned that yet couldn't affirm which is the energy source for chemical effort of protein synthesis from polyribosome level. In the conference end, during discussion time, a person from hall affirmed that the energy source for protein synthesis is doubtless inside mitochondria, which are in intimate contact with granular endoplasmic reticululm. The answer of GE Palade was "We also have thought to that, but the fact must be demonstrated".

Finally, it is necessary to be mentioned that even before he became Nobel Prize laureate GE Palade was honored for his scientific activity with other important prizes as Warren Triennial 1962, Passano 1964, Lasker 1966, Ducket Jones 1966, Louisa Gross Horowitz 1970 and Dickson 1971, and after Nobel Prize with cu Brown-Hasen 1983, Henry Gray 1986 and president Ronald Reagan conferred him the National Medal of Science in 1986. GE Palade was also invited in Pontifical Academy of Rome, where Pope Giovanni Paolo the second gave him a necklace in appreciation. When the Pope gave him the necklace, GE Palade said: "Holly Father, but I am orthodox, you must know!" and the Pope replied "No matter dear, for how many things you do for humanity you get over any denomination borders".

He was also elected "Doctor Honoris Causa" by universities from USA (Yale, Chicago, Philadelphia, Michigan, Ohio, New York and Columbia) and from abroad (Bern, Bristol, Siena, Uppsala). Since 1961, GE Palade became member of "US National Academy of Science".

Persons who known GE Palade, for example Keith Porter, James Jamieson, Alan Tartakoff, David Sabatini and Yutaka Tashiro, Günter Blobel and Ewald Weibel in different occasions have published articles about his role in development of Cellular Biology. The most ample biographical presentation was done by professor of Medicine History Radu Iftimovici who, in June 1991 in La Jolla, met GE Palade and their long and repeated discussions were recorded and formed the content of volumes in Romanian language "George Emil Palade, the first Romanian laureate of Nobel Prize" published in 1993 in Bucharest Romania and "Confession of a winner" published in 2006.

"There is no Prophet who is despised except in his country..."

(Matthew 13:57)

As concerns the relations of GE Palade with Romanian officials, it is known that before Nobel Prize (1974) he was considered apostate and his name maintained in anonymity. His visits in Romania were limited only to meet his mother and sisters. After 1975 the situation is changed, so GE Palade was elected honorific member of Romanian Academy, was decorated with Romania Star and in 2007 with Romania Star as Necklace Distinction, and in few city his name was gave to some colleges and streets. He made speeches only in the Institute of Cellular Biology and Pathology from Bucharest and in the Chemistry Institute from Cluj, but not in one of the six Medicine Universities from Romania. 
The GE Palade destiny was not unique. Numerous other intellectuals of Romania elite do not found in own country work conditions, comparable with those from developed and with old tradition countries, to be favorable for their vocation and competence validation, so they emigrated in countries, which could provide these vital conditions. In this case, it was confirmed what the American biochemist Vincent du Vigneaud (Nobel Prize 1955) said: "Nothing stop more the science progress than appropriate idea at unseasonable moment". It was the case of musicians George Enescu, Constantin Silvestri and Sergiu Celibidache, the philosopher Emil Cioran, the dramatist Eugen Ionesco, the sculptor Constantin Brâncuşi, the historian Mircea Eliade, the engineer Henri Coandă and the writers Elie Wiesel (Nobel Prize for Peace, 1986) and Herta Müller (Nobel Prize for Literature 2009). But even so, from abroad, always affirming their origin without reserves, they had promoted the prestige of their motherland country...

\section{REFERENCES}

1. Banca Națională a României: Emisiune numismatică monedă din argint dedicată aniversării a 100 de ani de la nașterea lui George Emil Palade

2. Darnel J, Lodish H and Baltimore D (1986). Molecular Cell Biologz. W.H. Freeman and Crup, New York.

3. Doherty Judi (1980). Un rol pentru un laureat al Premiului Nobel. The New Haven Register. doi:10.1172/ JCI37749 Obituary

4. Farquhar MG, Wissig SL, Palade GE (1999). Glomerular permeability I. Ferritin transfer across the normal glomerular capillary wall. 1961. J. Am. Soc. Nephrol. (United States) 10 (12): 2645-62. ISSN 1046-6673.PMID 10589706.

5. Hăulică I (2002). Professor George Emil Palade at 90 years of age. Revista medico-chirurgicală a Societăţii de Medici şi Naturalişti din Iaşi, 107(2): 223-225.

6. Iftimovici Radu (1977). Creaţia românească în biologia universală, Ed. Albatros, București.

7. Iftimovici Radu (1994). Istoria medicinei. Ed. ALL. București.

8. Iftimovici Radu (1993). George Emil Palade, primul român laureat al Premiului Nobel. Ed. Viitorul Românesc, București.

9. Jamieson DJ (1988). The exocrine pancreas, in "Cell and Tissue Biology". Ed. Leon Weiss, Urban and Schwarzenberg, Baltimore.

10. Jamieson JD (2008). A tribute to George E. Palade. November 8, 2008

11. Jamieson JD (2009). George E. Palade EM Slide Collection, Henry Cushing and Hay Whitney Medical Library, Yale, USA. http://cushing.med.yale.edu/gsdl/collect/palade
12. Motta PM (2001). George Emil Palade and Don Wayne Fawcett and the development of modern anatomy, histology and contemporary cell biology.Italian journal of anatomy and embryology [Archivio italiano di anatomia ed embriologia] (Italy) 106 (2 Suppl 1): XXIXXXVIII. ISSN 1122-6714.PMID 11730003.

13. Muscan Catinca (1982). Despre Această etică a cunoaşterii. Almanahul revistei Steaua, Cluj.

14. NEWS ALERT: A murit Emil Palade realitatea.net, accesat 8 octombrie 2008

15. Palade George E. (2008) Autobiography. Nobelprize.org. 2008-10-07. Retrieved 2011-04-03.

16. Palade George Emil (1974). Banquet Speech. The Nobel Foundation, Stockholm.

17. Palade George Emil (1974). Intracellular aspects of the process of protein secretion. Nobel Lecture, December 2, 1974, Nobel Foundation, Stockholm.

18. Porter KR (1983). An informal tribute to George E. Palade. $J$. Cell Biol. (United States) 97 (1): D3-7. ISSN 00219525. PMID 6345553.

19. Raju TN (1999). The Nobel chronicles. 1974: Albert Claude (1899-1983), George Emil Palade (b 1912), and Christian Réne de Duve (b 1917). Lancet (England) 354 (9185): 1219. doi:10.1016/S0140-6736(05)75433-7.ISSN 01406736. PMID 10513750.

20. Sabatini DD (1999). George E. Palade: charting the secretory pathway. Trends Cell Biol. 9(10): 413-417.

21. Simionescu N and Maya Simionescu (1988). The cardiovascular system, in "Cell and Tissue Biology". Ed. Leon Weiss, Urban and Schwarzenberg, Baltimore.

22. Singer, Manfred V (2003). Legacy of a distinguished scientist: George E. Palade. Pancreatology (Switzerland) 3 (6): 518-9. doi:10.1159/000076328. ISSN 1424-3903. PMID 14730177.

23. Tartakoff, AM (2002). George Emil Palade charismatic virtuoso of Cell Biology. Nat. Rev. Moll. Cell. Biol. 3(11): 871-876.

24. Tashiro Y (1975). Accomplishment of Drs. Albert Calude and George E. Palade and the birth of cell biology. Tanpakushitsu Kakusan Koso (Japan) 20(1): 74-6. ISSN 00399450. PMID 1094498.

25. The Independent (2008). Prof. George Palade: Nobel prize-winner whose work laid the foundations for modern molecular cell biology. 22 October 2008. Retrieved 2011-0209. Archived

26. The preceding Romanian translation of the quotation from Dr. George E. Palade's "Autobiography" is Copyright (C20082011 by Dr. I. C. Baianu, (in USA)

27. US NSF - The President's National Medal of Science: Recipient Details

28. Weibel ER, Palade GE. (1964). New cytoplasmic components in arterial endothelia. J. Cell. Biol. 1964, 23: 101-112).http:// www.jcb.org/cgi/content/abstract/23/1/101

29. http://wikipedia , the free encyclopedia: George Emil Palade, Biography.

30. http://cushing.med.yale.edu/g sdl/cgi-bin/ library? $=$ palade $\& p=$ about

31. http://library.medicine.yale.edu/ 
32. http://nobelprize.org/nobel_prizes/medicine/laureates/1974/ palade-autobio.html

33. http://nobelprize.org/nobel_prizes/medicine/laureates/1974/ palade-lecture.pdf The Nobel Prize Lecture of George E. Palade is in Text Format Pdf 3.78 MB, Copyright $@ 1974$ by The Nobel Foundation, ISBN 981-02-0791-3

34. http://nobelprize.org/nobelfoundation/publications/lectures/ WSC/physio-71-80.html

35. http://www.nobelprize.org/nobel_organizations/ nobelfoundation/publications/lesprix.html

36. http://www.nobelprize.org/nobel_prizes/medicine/ laureates/1974/claude.html
37. http://www.nobelprize.org/nobel_prizes/medicine/ laureates/1974/duve.html

38. http://www.nobelprize.org/nobel_prizes/medicine/ laureates/1974/palade-facts.html

39. http://www.nobelprize.org/nobel_prizes/medicine/ laureates/1974/palade-lecture.pdf

40. http://www.nobelprize.org/nobel_prizes/medicine/ laureates/1974/palade.html

41. http://www.rockefeller.edu/nobel.html

42. https://www-er.ucsd.edu/givetoucsd/secure/paymenttran/ onlinegiving.asp?sk=224 